\title{
Formulating Criminal Liabilities Regarding Online Prostitution
}

\author{
Trio Angga Laksana \\ University of Jember, Indonesia \\ trio_angga@yahoo.co.id
}

\section{Y.A.Triana Ohoiwutun}

University of Jember, Indonesia

trianaohoiwutun@unej.ac.id

\author{
Fanny Tanuwijaya \\ University of Jember, Indonesia \\ fanny.tanuwijaya@unej.ac.id
}

\begin{abstract}
This study aims to obtain similarities and differences regarding legal formulation in online prostitution. Hitherto, prostitution has remained to exist in Indonesian society. In context, the existing perpetrators of prostitution do not peddle conventionally but also virtually, in which online prostitution that gradually increases is a common term that refers to this phenomenon. The current law enforcement against perpetrators of online prostitution performs as the consequence of the national law in which national laws have yet remained to accommodate in criminalizing perpetrators of online prostitution. The criminalization of perpetrators in online prostitution may contrast with the principle of legality so that national laws should accommodate perpetrators of online prostitution regarding their criminal liability. In particular, these national laws should address whether to prohibit the attitude that proliferates online prostitution so that perpetrators of online prostitution should be accountable for their crimes. Henceforth, this measure intends to avoid the overlap of the principle of legality in criminal law.
\end{abstract}

KEYWORDS: Online Prostitution, Criminal Liabilities, Principle of Legality.

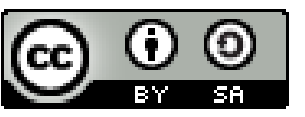

Copyright $\odot 2019$ by Author(s)

This work is licensed under a Creative Commons Attribution-ShareAlike 4.0 International License. All writings published in this journal are personal views of the authors and do not represent the views of this journal and the author's affiliated institutions.

\section{HOW TO CITE:}

Laksana, Trio Angga, Y.A. Triana Ohoiwutun \& Fanny Tanuwijaya. "Formulating Criminal Liabilities Regarding Online Prostitution" (2019) 6:3 Lentera Hukum 431-444.

Submitted: December 03, 2019 Revised: December 07, 2019 Accepted: December 31, 2019 


\section{INTRODUCTION}

In this globalized world, crimes no longer exist conventionally as their consequences refer to the Criminal Code but also virtually, using technology, which are beyond the Criminal Code. A significant and profound development in technology has encouraged people to use smartphones and computers, which have become common tools to interact with each other. On the other hand, such tools are pervasively used as instruments committing to crimes. The rapid development of information and communication provides a change in human morals and relationships so that many people may commit crimes using these tools. One of these crimes is prostitution; it includes a new job to commit various sexual crimes and get a wage. ${ }^{1}$ In particular, prostitution is a form of crime that violates decency in people's lives that has a negative impact is a form of undesirable action that can cause disunity in the family. ${ }^{2}$

Conventional prostitution can be interpreted as an action where someone offers and sells the body to others leading to sexual exploitation to get wages as a result of services as promised. Online prostitution is slightly different from conventional prostitution, referring to the way of offering or selling it through electronic instruments or other online media, including social media such as WhatsApp, Facebook, Instagram, and others. ${ }^{3}$ While perpetrators of online prostitution have entered into cyberspace, referring to term online prostitution, they peddle themselves through these online instruments. The use of online media has become a more accessible means for crimes because the perpetrators and their customers conduct transactions using online technological instruments, which can provide convenience for the perpetrators and users of prostitution services online. ${ }^{4}$

The courts have ruled decisions against online prostitution occurred in Indonesia, under Article 27 (1) of the Act information and Electronic Transaction (UU ITE). First, the Decision of the Pangkalpinang District Court Number: 228/Pid.B/2015/PN Pgp on the act of offering several women to men using the Blackberry Messenger (BBM) facility to have intimate relationships. Secondly, the Sleman District Court Decision Number: 516/Pid.Sus/2017/PN Smn JP was made a Twitter account with the name Ricky GIGOLO INDO has posted words offering to find customers for themselves as perpetrators of prostitution online. Third, based on the Padang IA Class District Court Decision Number 393/Pid.B/2014/PN.Pdg on the act of DM sent a short message service (SMS) containing words to have intimate relations with the three victims named NK, MR, FD.

The Swedish state has conventionally arranged prostitution as an act that can be convicted. Since the enactment of the prostitution ban law in Sweden, prostitution has

\footnotetext{
Soejono Soekanto, Sosiologi Suatu Pengantar (Jakarta: Raja Grafido Persada, 2010) at 328.

Ibid.

Widodo, Hukum Pidana di Bidang Teknologi Informasi (Yogyakarta: Aswaja Pressindo, 2013) at 5.

Melinda Arsanti, "Penggunaan Media Sosial Sebagai Sarana Prostitusi Online" (2017) Jurnal Ilmu Komunikasi at 51 .
} 
decreased by 50\%. ${ }^{5}$ Besides, according to Swedish foreign minister Margot Wallström, since the enactment of the respective act, prostitution in Sweden has declined compared to some years before the enactment of the Sex Purchase Act. ${ }^{6}$ Sweden in regulating online prostitution can impact on suppressing prostitution, and Indonesia must adopt the same. According to preceding, the problems arises against a criminal liability of perpetrators online prostitution. It is essential to analyze problems such as how liabilities perpetrators online prostitution according to Article 27, paragraph 1 of UU ITE, and the ideal formulation policy in criminal liability for perpetrators of online prostitution.

This study aims to obtain similarities and differences regarding legal formulation in online prostitution. This paper uses legal research by studying and analyzing legal materials and legal issues related to the problem. This study uses the legislative approach to examine the legislation relating to prostitution and electronic Acts. ${ }^{7}$ This study also applies the conceptual approach by referring to doctrines ${ }^{8}$ and under various cases that are related to both legal issues. ${ }^{9}$ The decisions analyzed are Decision of Pangkalpinang District Court with Number: 228/Pid.B/2015/PN Pgp., Decision of Sleman District Court with Number: 516/Pid.Sus/2017/PN Smn., Decision of District Court of Padang IA Class with case number 393/Pid .B/2014/PN.Pdg. In addition, this study uses a comparative approach, comparing Sweden, whose legal system is different from Indonesia, but with similar cases on how the governments regulate and criminalize prostitution following perpetrators' liabilities regarding online prostitution both conventionally and virtually. ${ }^{10}$

\section{CRIMINAL LIABILITIES REGARDING PERPETRATORS OF ONLINE PROSTITUTION UNDER ARTICLE 27 (1) OF UU ITE}

Criminal liability has an extensive scope, according to the international convention of criminal liability, as Teorekenbaardheid or criminal liability, whose orientation regards the penalization of crimes. Criminal liability as a final of behavior can justify as crime; a person can be criminalized: ${ }^{11}$

a. A person who takes a behavior against the law, mostly they doing against the law is an objective element of a criminal requirement;

\footnotetext{
5 Tempo, "Swedia Berhasil Atasi Prostitusi, Begini Caranya" (2019), online: 〈https://dunia.tempo.co/read/666404/swedia-berhasi-atasi-prostitusi-beginicarnya/〉.

6 Regeringen, "Vi Tar Kampen Mot Prostitution", (2019), online: 〈https://www.regeringen.se/debattartiklar/2019/03/vi-tar-kampen-mot-prostitution/>.

7 Peter Mahmud Marzuki, Penelitian Hukum (Jakarta: Kencana Prenada Media Grup, 2016) at 33.

8 Ibid.

9 Made Pasek Diantha, Metodologi Penelitian Hukum Normatif (Jakarta: PT. Kharisma Putra Utama, 2016) at 165.

10 Peter Mahmud Marzuki, supra note 7 at 167.

11 SR Sianturi, Asas-Asas Hukum Pidana Indonesia dan Penerapannya (Jakarta: Alumni Ahaem-Petehaem, 1996) at 245.
} 
b. Perpetrators deliberate negligence, whose actions are under criminal liability.

Van Hemel argues that criminal liability is a reasonable condition of psychologically and a proficiency that exist in all three abilities, firstly, depending on the ability to understanding the meaning of the actions by himself. Secondly, the competences to mindful of if his actions are carried out contradicting the existing order in society. Thirdly, he has the ability to doing volition. ${ }^{2}$ The aim of the statement for the perpetrators of crime must develop understanding and the ability to criminal liability.

The substantial responsibility is an absolute element of criminal liability because if someone is unresponsible, it is unlogic that he makes it for himself. Simons argues that the ability to be responsible is a mental description for the implementation of punishment, from the general and personal viewpoints. Simons's statement illustrated the subsistence of perpetrators' ability. The concept of criminal liability is not only based on the ability to be responsible but also to the existence of the perpetrator's fault. Based on a foreign language, a malfunction is a mens rea, and it is not on his actions but the inner attitude of the perpetrators. This principle requires that there are two elements of guilty feeling to penalize. First, actions are prohibited by criminal law. Second, there is a despicable inner attitude towards perpetrators. ${ }^{13}$

In contrast to Moeljatno, responsibility without error is called Leer van het materiele feit. It represents in several violations, but since Arrest is milk HR 1916 Nederland, it has not applied against offenses of the type of overtredingen, a principle that is without error, no crime. ${ }^{14}$ Again, in contrast to Moeljatno, liability without mistake is called Leer van het materiele feit. It exemplifies in several violations, but since Arrest on HR 1916 Nederland, it has not conducted against offenses of the type of overtredingen, a principle that is without error, no crime. ${ }^{15}$ A person can be blamed on behavior if at the time of acting a behavior. In particular, it deals with the consequence of the behavior. A person knows that the consequences come up from a respective behavior so that it can be called perpetrators motive, interpreted by some experts as a will or desire to bring up behavior. There are two theories relating to intention. They are the theories of the will and knowledge. Moeljatno's theory more inclined to the theory of knowledge or imagine on the occasion that if perpetrators have a motive to do various activities and knowledge or imagine from consequences obtained. ${ }^{16}$

According to Moeljatno, differently from culpa or omission, but it has the same basis that is equally prohibited by criminal law and threatened with crime can be justified. There is no forgiving reason. ${ }^{17}$ The reasons for forgiveness arise when a person's actions have value against the law, but some actions can be forgiven.

\footnotetext{
12 Eddy OS Hiariej, Prinsip-Prinsip Hukum Pidana Edisi Revisi (Yogyakarta: Cahaya Atma Pustaka, 2016) at 37.

13 Mahrus Ali, Dasar-Dasar Hukum Pidana (Jakarta: Sinar Grafika, 2011) at 155.

14 Moeljatno, Asas-asas Hukum Pidana (Jakarta: Bina Aksara, 2009) at 165.

15 Ibid.

16 Moeljatno, Asas-asas Hukum Pidana (Jakarta: Intermasa, 2002) at 165.

17 Ibid.
} 
Forgiveness is a subjective reason that a person unconvicted. ${ }^{18}$ Roslan Saleh argues that if a defendant's actions can be accounted for if their actions against the law, then the firstly, they can be able to ensure the existence of a criminal act after that the elements can be sentenced was linked to criminal liability. ${ }^{19}$ Roslan Saleh's opinion was providing illustrations if every act can be accounted for by the offender if it has violated criminal law and associated with the form of liability, then the perpetrators are accountable for their actions. The offenses using online media are closely related to electronic information or electronic documents. The uses of these facilities provide convenience to perpetrators of a crime, carrying out actions which prostitution that was original manner to do conventionally with their means of electronic information or electronic documents makes him easy. Currently, prostitution activities with electronic information facilities or electronic documents refer to online prostitution.

Prostitution comes from Latin, which means "pro-stituere" means to surrender openly to commit adultery, commit prostitution, sexual immorality, and fornication. These words are etymologically also associate with Prostate, namely buy and sell. The Greco-Romans have used these words from ancient times for a woman who sold her body. ${ }^{20}$ Paul Moedikdo Moeliono interprets prostitution as the surrender of a woman's body accompanied by payment. This act aims to satisfy people's desires. ${ }^{2 l}$ WA Bonger, from his article Maatschappelijke Darsaken Des Prostitutie, prostitution is considered a symptom in a society where a woman sells herself to do sexual crime to gain profit as her livelihood. ${ }^{22}$

Prostitution indicates a sexual relationship between a woman and a man without any marital status. Women and men can do prostitution, so it is considered the same between women and men who have sex outside of legal marriages. ${ }^{23}$ In this study, the types of prostitution in question are called prostitution and covert prostitution. Prostitution has a widespread impact than street prostitution or brothel prostitution from buy and sell transactions on-call prostitution and covert prostitution unconventionally but virtually in every single day. The meaning of virtual is a place to share information via the internet; according to Dedik Kurniawan, online indicates an activity that uses internet networking for several activities such as business, communication, others. ${ }^{24}$

In particular, prostitution is an undesirable action as a form of crime in people's lives. Islamic law also prohibits the existence of prostitution in Surah Al Isra 'verse 32.

18 Widhiana Suarda, Hukum Pidana: Materi Penghapus, Peringan dan Pemberat Pidana (Malang: Bayumedia Publishing, 2012) at 121.

19 Roeslan Saleh, Pikiran Pikiran Tentang Pertnaggungjawaban Pidana (Jakarta: Ghalis Indonesia, 1982) at 54 .

20 B Simandjuntak, Pengantar Kriminologi dan Patologi Sosial (Bandung: Tarsito, 1981) at 280.

21 Yesmil Anwar dan Adang, Kriminologi (Bandung: PT. Refika Aditama, 2013) at 363.

22 Kartono Kartini, Patologi Sosial (Jakarta: Raja Grafindo Press, 2005) at 214.

23 Mulia TSG, Seks, Uang dan Kekuasaan, Ter. Ade Armando (Jakarta: LP3ES: Anggota Ikapi, tt) at 15.

24 Dedik Kurniawan, Membangun Bisnis Sekolah Online (Jakarta: PT. Alek Media Komputindo, 2013) at 168 . 
For Muslims, religious adultery is strongly opposed to adultery committed on prostitution to explain if the action of prostitution undesirable by society; it qualified as a form of crime that can be convicted. In connection with crimes that can be convicted according to Piers Beire and James W. Messerschmidt argues that if the crime called a legal definition of crime can be distinguished as mala in se and mala prohibita. Mala in se can be called a crime because the action was beginning as an evil act because it is contrary to the rules and a norm was living in society before they stipulated in a law as crimes that can be convicted. Malum prohibition can be identified as a violation of the applicable law. ${ }^{25}$

The concept of criminology, mala in se is a crime from sociological sense, which is an act that was considered to be generally reprehensible in the view of society, although it has not included in the legislation. In contrast, mala prohibita is a crime in the juridical regulated in statutory laws. ${ }^{26}$ Prostitution is a despicable deed that was contrary to law and norms, which developing in society so that prostitution can be qualified as a form of crime in society. Therefore it can be categorized as mala in se. Cases in Indonesia, which can include crimes of online prostitution, are in the Pangkalpinang District Court, Sleman District Court, and the Padang IA Class District Court. The three cases from tribunal decisions using the provisions of Article 27 paragraph 1 of UU ITE. The elements of Article 27 paragraph 1 of UU ITE cannot include criminalizing perpetrators of online prostitution due to the absence of the Online Prostitution Act. If Article 27 paragraph 1 of UU ITE is applied to online prostitution, it may result in obscurity and for which the legal conflict will be unavoidable. Besides, the application of the provisions of Article 27 paragraph 1 of UU ITE on three cases above, which is due to violation decency by three perpetrators, was distributing content. The perpetrators in the three cases above are very under the act of online prostitution because hitherto, it has not yet been regulated the provisions prohibiting online prostitution perpetrators.

Criminal liability against perpetrators of online prostitution cannot be accounted for and held liable as a crime. Furthermore, the criminal liability system on UU ITE would not be applied. While the provisions of liability in UU ITE are enforced against online prostitution crimes, it contradicts the principle of criminal law, the principle of legality. The principle of legality contains in Article 1 paragraph (1) of the Criminal Code, according to its formulation in the Dutch language: "Geen feit I strafbaar and uit kracht van een daaran voorafgegane wettelijke strafbepaling." Zainal Abidin Farid translates it as: "No event can be convicted other than the strength of the provisions of the criminal law that preceded it." ${ }^{\prime 7}$

Nevertheless, in his book "Indonesian Criminal Law," written together with Andi Hamzah, the formulation of Article l paragraph (1) is translated as: "no act that can be

25 Eddy OS Hiariej, supra note 13 at 101-102.

26 Deni SB Yuherawan, "Kritik Ideologis Terhadap Dasar Kefilsafatan Asas Legalitas Dalam Hukum Pidana" (2012) 12 JDH at 222.

27 HA Zainal Abidin Farid, Hukum Pidana l (Jakarta: Sinar Grafika, 2007) at 130. 
convicted other than based on the provisions of criminal legislation that preceded it. ${ }^{128}$ It means that all forms of crimes that have not been regulated in the provisions of criminal law; such actions cannot be qualified as crimes. If they are associated with online prostitution wherein Indonesian legal rules are still unclear to accommodate, online prostitution, according to the principle of legality is not a crime. However, these actions include actions that are contrary to the law that develops in people's lives or norms in society. In connection with conventional and prostitution offenders online in the 2018 Draft Criminal Code, there is still no precise regulation related to online prostitution offenders. They are regulated only by pimps or intermediaries from prostitution, even though Indonesia needs this regulation on the prohibition of prostitution online. Given the crime of perpetrators, online prostitution is increasingly prevalent in some regions, and perpetrators of online prostitution cannot be accounted for a crime.

Indonesia still has unclear progress in regulating online prostitution. In contrast, in 1999, Sweden regulated the act of prostitution in the provisions of criminal code, which included explicitly in the Sex Purchase Act Swedish. The Sweden regulations have a positive impact on the suppression of prostitution since the enactment of regulation in prostitution activities experienced a rapid decline, comparing to before the formulation of prostitution regulation in Swedish law.

The application of the rule of law regulation against online prostitution must be precise. If the rule of law regulation is unclear and vague, it is contrary to legal certainty. Legal certainty is a definite, not obscure, clear, stipulated, and statutory condition. The law entity must be fair and specific so as not to cause multiple interpretations, the definite meaning as a guide for behavior. In contrast, the fair meaning of the behavior must prioritize a fair value order, if the provisions of Article 27 paragraph 1 of UU ITE applied to online prostitution would certainly be vague, and its application would be vague, and it is not clear then, of course, this is contrary to legal certainty. Besides, Indonesian criminal law adheres to the principle of law that is the principle of legality in every rule of law. It asserts impossibility for a person to be convicted unless the rules are included in a criminal code as it refers to the principle of legality is contained in article 1 , paragraph 1 of the Criminal Code. If it is related to prostitution crime online, because online prostitution is still not regulated in the Indonesian criminal code both in the Criminal Code and in the special law, namely UU ITE, it is clear that prostitution crime online is not a crime. If the provisions in both in UU ITE and the Criminal Code are forced to ensnare perpetrators of online prostitution, it is certainly contrary to the principle of legality in criminal law.

28 HA Zainal Abidin Farid \& Andi Hamzah, Hukum Pidana Indonesia (Jakarta: PT. Yarsif Watampone, 2010) at 53. 


\section{FORMULATING LIABILITIES IN ONLINE PROSTITUTION}

A legislator formulated the law enforcement of the nation. The implementation and application to better determine and accountability. It is often interpreted as the legislative stage. According to Barda Nawawi Arief, legislative policy is a plan or program of legislators regarding works with specific problems and how to implement something planned or programmed for the future. Errors in the formulation policy stage are mistakes that can hinder the law enforcement process. ${ }^{29}$ From the criminal law policy at the stage, formulations must be calculated in detail. So that in the application to enforce the law to be good and there are no obstacles, if it is wrong in the stage formulation, then it will arise are obstacles in the process of law enforcement. It will undoubtedly affect the accountability of system criminal offense. Efforts to establish proper legal regulations will never be separated from the goal of criminal prosecution. It means that criminal law policy is synonymous with crime prevention by using criminal law. $^{30}$

Furthermore, the formation of legislation at this stage of formulation is also a basic form of protecting the public, so it is very natural to say that criminal law politics is an integral part of social policy. The stage formulation is part of the criminal law policy on the penal policy. Accordingly to Barda Nawawi Arif, criminal law policy is a science that can also be categorized as an art that has a practical purpose to be able to formulate excellent regulation and to provide a guide not only making laws and regulations but also to executors in tribunal decision. ${ }^{31}$ It means that criminal law policy is not only the responsibility of legislators but also for every implementer of the law, and to make great laws requires some other knowledge.

Online prostitution is a crime that can be detrimental to the order of a society, a lot of the impact of prostitution crimes online to people's lives in developing norms in public life clear categorize crimes prostitution online is a disgraceful act. Accountability to perpetrators of online prostitution is not only enough to categorize online prostitution crimes as crimes in society but must be formulated in the form of laws and regulations so that the law enforcement becomes clear. The strong points of the policy formulation of criminal law consist of several things. First, formulating a criminal act is an act that can be carried out against the perpetrators. The formulation of a conviction must have to elements of a person who does a correction, and in essence, who can commit a criminal offense, namely a person or human being. Crimes that can be convicted are crimes against the law, which must meet the elements of the offense formula contained in the provisions of the law. These actions can be interpreted as

\footnotetext{
29 Ridwan, Kebijakan Formulasi Hukum Pidana Dalam Penanggulangan Tindak Pidana Korupsi, 1 (2013) at 204.

30 Barda Nawawi Arief, Bunga Rampai Kebijakan Hukum Pidana, Edisi Kedua Cetakan ke-4 (Jakarta: Kencana, 2014) at 251.

31 Ibid.
} 
doing or not doing something. In addition to the element of unlawful conduct, there must be a loss regarding the victim of the act. ${ }^{32}$

Second, the formulation of criminal liability. A person who commits a criminal act may not necessarily be subject to criminal conduct, but the convicted data must meet two conditions, namely. First. The act must be a criminal offense. Second, the perpetrators must be accountable. Determining the first condition is closely related to the principle of legality, while for the second condition is a mistake, it is related to the person who is doing and the inner attitude of the criminal or related to criminal liability - knowing the element of mistakes is determine the existence of criminal liability based on the principle of mistake. Another word of the principle of fault that is not convicted if there is no error, Principles, Culpabilitas Principle straf zonder geen Schuld. . $^{33}$

Third, the formulation of Sanctions. The system of mitigation in imposing criminal sanctions by using criminal legal means, namely with criminal formulation sanctions. Criminal sanctions are tough sanctions in the form of punishment to someone rather than civil sanctions and administrative sanctions. Roeslan argues that a crime is a reaction to the offense in the form of a misery deliberately, given by the state to the perpetrators. ${ }^{34}$

Roeslan's statement is under Van Bemmelen's statement. ${ }^{35}$ Criminal law determines sanctions against violations of prohibition rules. The sanction is, in essence, an increase of suffering done deliberately. Determine the composition of the type of punishment of severe and light punishment but must also be considered the reasons contained in criminal law and the purpose of punishment. The formulation of sanctions must adjust to the needs of the community. The limits must also be adjusted to the interests and values in community life. On the other hand, giving sanctions to perpetrators of crime must also provide awareness of the perpetrators of crimes as in the purpose of criminal law. Concerning online prostitution crime, sanctions in the form of punishment for perpetrators based on the theory of criminal law are not merely as a final goal but as the closest objective, namely to provide retaliation to online prostitution perpetrators to realize that punishment is a result of their actions. On the other hand, criminal prosecution of perpetrators of online prostitution aims to create order in people's lives, online prostitution in people's lives has a terrible impact not only that, prostitution online in people's lives is considered as a despicable act and contrary to norms existing in people's lives. The absence of proper legal rules in the Criminal Code and UU ITE relating to online prostitution crimes as a crime makes a situation in society chaotic resulting in online prostitution becoming rampant in

32 Dey Revana \& Kristian, Kebijakan Kriminal Criminal Policy (Jakarta: Kencana Prenada Media Group, 2017) at 148.

33 Sudarto, Hukum Pidana I (Semarang: Badan Penyedia Bahan-bahan Kuliah Undip, 1987) at 85.

34 Roeslan Saleh, supra note 20.

35 Van Bemmelen, Hukum Pidana I Hukum Pidana Material Bagian Umum Cet. 2 (Bandung: Bina Cipta Bandung, 1987) at 17. 
various regions in Indonesia, the chaos is under the theory of criminology namely the anomie theory.

Anomie theory is a term that was introduced by Emile Durkheim, to describe a chaotic situation, without rules. This word comes from Greek "without" and "Nomos": "law" or "regulation." The term was also put forward by Robert K. Merton, whose purpose was to describe the state of deregulation in his society. This situation means that the rules contained in the community are not obeyed, and people do not know what is expected by that person, the condition of this normless society, which causes deviant behavior. For example of this theory is the case of a beast who is punished for abusing authority in tax revenue. ${ }^{36}$ Furthermore that if there are no criminal regulations against an act that is considered a criminal offense, it will cause some irregularities in people's lives. It is following the current state of Indonesia because no Online prostitution is regulated, resulting in several regions becoming epidemic. However, prostitution is conventionally carried out in the form of a closure of a localization site, but the perpetrators used another method, namely, through online prostitution.

The Theory was forward by Durkheim, who stated that in modern society, traditional standards and norms are in vain and without a substitute for new ones, which results in the collapse of the norms that govern each person in behavior. This condition explained without rules is called anomie, where there are no norms that regulate people's lives, so what happens next is tension in society. ${ }^{37}$

This anomie theory according to Emile Durkheim has three views, viz., (a) humans are social creatures; (b) humans its existence is considered a social creature; and (c) in a society, people tend to live, and humans always depend on the community as a group. ${ }^{38}$ Online prostitution, which is still not regulated provides norms deviation in the life of the community, which is usually the norms in the community obeyed but because of the absence of these rules makes the norms in the community not enforceable so that the result that will cause is tension in the community. Accordingly, Anomie's theory is a condition wherein a society, there is no opportunity, and there are differences in the structure of opportunities to achieve a goal (ideals). Both of these factors cause people to become frustrated, become conflicted, the dissatisfaction of fellow individuals, the closer they are to conditions that are not based on prevailing norms. ${ }^{39}$

Accordingly, the anomical theory, the crime will arise due to the absence of legal rules in the community, so it can be interpreted that online prostitution exists and continues to develop in people's lives because of the absence of norms governing online prostitution crimes, to protect the public from online prostitution requires the criminalization of the crime by regulating it in the rule of law. Formulating the

36 J Sahalessy, "Jurnal Ilmiah Fakultas Hukum Universitas Pattimura Ambon" (2015) 21 SASI at 42.

37 Feryna Nur Rosyidah \& M Fadhil Nurdin, "Perilaku Menyimpang: Media Sosial Sebagai Ruang Baru Dalam Tindak Pelecehan Seksual Remaja" (2018) 2 JP\& $\&$ S at 44.

38 Lilik Mulyadi, Bunga Rampai Hukum Pidana Perspektif, Teoretis, dan Praktik (Bandung: PT. Alumni, 2008) at 325.

39 Yesmil Anwar \& Adang, Kriminologi (Bandung: Refika Aditama, 2010) at 88. 
accountability of perpetrators of online prostitution must be determined in advance by the system of criminal liability and its penalties. Therefore, there is a need an effort to reformulate criminal liability of perpetrators regarding online prostitution in the future. The formulation of online prostitution provisions must be strictly regulated so that perpetrators of online prostitution can be criminally accountable. Based on the explanation above, the formulation policy is a strategic stage because if it is wrong in the formulation stage, it will harm the next stage, namely the application stage and the execution stage. The most critical point in the formulation stage is to formulate an excellent regulation, meaning that the formulation of the rule of law must be taken into account so that in its implementation, there are no unwanted obstacles.

Under the theory of the purpose of criminal law, the formulation of sanctions must provide awareness for the perpetrators of a crime. The perpetrators' awareness is the most crucial element in the theory of criminal law objectives, while punishment is a form of awareness for the offender that the punishment is the result of his actions so that with an awareness of perpetrators will no longer commit a crime. Also, punishment is considered as a protection of the interests of the community. Crimes will arise when there are no rules that govern them. If the regulation is clear and specific, crime will not potentially develop in society. Where crime arises as a result of the absence of legal rules are clearly and govern it under one of the criminological theories, namely the anomie theory. Anomie's theory, according to Durkheim, is a condition without norms that creates chaos that gives birth to a crime, meaning that crime arises because there is no legal rule governing it. This study justifies that online prostitution still exists in people's lives because no regulation to address online prostitution.

The legal formulation must pay attention to the excellent formulation and can be carried out at the next stage, namely application and execution. The legal formulation of online prostitution will produce a new legal product regarding the prohibition of online prostitution perpetrators, of course, the prohibition must contain elements of online prostitution crime, namely first, crimes to surrender themselves to the general public. Second, sexual intercourse, and third, there are personal benefits by using online means to carry out the transaction. However, the provisions do not apply to a prostitute who is in a state of helplessness so that by formulating the provisions of the online prostitution law, online prostitution can be accounted for a crime.

\section{CONCLUSION}

The criminal liability of perpetrators of online prostitution in Article 27 paragraph 1 of UU ITE cannot be accounted for a crime because there is an unclear accommodation to criminalize perpetrators of online prostitution under UU ITE. The absence of online prostitution legal rules makes these actions can not be declared a criminal offense, and if forced by UU ITE to ensnare perpetrators of online prostitution, it will be contrary to 
the principle of legality. Indonesia can adopt the Swedish law provisions on the prohibition of prostitution beside Indonesia regulates the prohibition of online prostitution perpetrators. The actions of the perpetrators of online prostitution can be accounted for a crime, and this will minimize online prostitution in Indonesia.

The legal formulation for perpetrators of online prostitution crimes includes paying attention to the proper formulation, and it should be carried out for law enforcement. Indeed, the prohibition must contain elements of online prostitution, namely, first, the act of surrendering itself to the general public. Second, sexual intercourse and third, there are personal benefits by using online means to carry out their transactions, and criminal liability can be applied to perpetrators of online prostitution. However, if it happens to someone helpless, then these provisions cannot be applied, as the formulation of the perpetrator's policies. Online prostitution will not occur violations of the principle of legality in its future application.

Indonesian law currently still has limitations on the criminal liability of perpetrators of online and conventionally prostitution, because the rule of law of Indonesia until now did not accommodate it. Therefore there is a need for renewal in the national legal rules, namely, in the Criminal Code and UU ITE relating to criminal liability of perpetrators of online prostitution. Also, there needs to be a change in the Criminal Code and UU ITE so that the criminal liability of online prostitution perpetrators is formulated in detail so that later online prostitution perpetrators can be criminally accounted for otherwise. The formulation will protect people's lives.

\section{REFERENCES}

Arsanti, Melinda. "Penggunaan Media Sosial Sebagai Sarana Prostitusi Online" (2017) Jurnal Ilmu Komunikasi.

B Simandjuntak. Pengantar kriminologi dan Patologi Sosial (Bandung: Tarsito, 1981).

Barda Nawawi Arief. Bunga Rampai Kebijakan Hukum Pidana, edisi kedua cetakan ke-4 (Jakarta: Kencana, 2014).

Dedik Kurniawan. Membangun Bisnis Sekolah Online (Jakarta: PT. Alek Media Komputindo, 2013).

Deni SB Yuherawan. "Kritik Ideologis Terhadap Dasar Kefilsafatan Asas Legalitas Dalam Hukum Pidana” (2012) 12 JDH.

Dey Revana \& Kristian. Kebijakan Kriminal Criminal Policy (Jakarta: Kencana Prenada Media Group, 2017).

Dyah Ochtorina Susanti \& A'an Efendi. Penelitian Hukum (Legal Research) (Sinar Grafika, 2014).

Eddy OS Hiariej. Prinsip-Prinsip Hukum Pidana Edisi Revisi (Yogyakarta: Cahaya Atma Pustaka, 2016).

Feryna Nur Rosyidah \& M Fadhil Nurdin. "Perilaku Menyimpang: Media Sosial Sebagai Ruang Baru Dalam Tindak Pelecehan Seksual Remaja” (2018) 2 JP\&PS. 
HA Zainal Abidin Farid. Hukum Pidana l (Jakarta: Sinar Grafika, 2007).

HA Zainal Abidin Farid \& Andi Hamzah. Hukum Pidana Indonesia (Jakarta: PT. Yarsif Watampone, 2010).

I Made Pasek Diantha. Metodologi Penelitian Hukum Normatif (Jakarta: PT. Kharisma Putra Utama, 2016).

J Sahalessy. "Jurnal Ilmiah Fakultas Hukum Universitas Pattimura Ambon" (2015) 21 SASI.

Kartono Kartini. Patologi Sosial (Jakarta: Raja Grafindo Press, 2005).

Lilik mulyadi. Bunga Rampai Hukum Pidana Perspektif, teoritis, dan Praktik (Bandung: PT. Alumni, 2008).

Mahrus Ali. Dasar-Dasar Hukum Pidana (Jakarta: Sinar grafika, 2011).

Marzuki, Peter Mahmud. Penelitian Hukum (Jakarta: Kencana Prenada Media Grup, 2016).

Moeljatno. Asas-asas Hukum Pidana (Jakarta: Intermasa, 2002).

-—- Asas-asas Hukum Pidana (Jakarta: BinaAksara, 2009).

Mulia TSG. Seks, uang dan kekuasaan, Ter. Ade Armando (Jakarta: LP3ES: Anggota Ikapi, tt).

Regeringen, "Vi Tar Kampen Mot Prostitution" (2019) online:

〈https://www.regeringen.se/debattartiklar/2019/03/vi-tar-kampen-motprostitution/>.

Ridwan. Kebijakan Formulasi Hukum Pidana Dalam Penanggulangan Tindak Pidana Korupsi, 1 (2013).

Roeslan Saleh. Pikiran Pikiran Tentang Pertnaggungjawaban pidana (Jakarta: Ghalis Indonesia, 1982).

Soekanto, Soejono. Sosiologi Suatu Pengantar (Jakarta: Raja Grafido Persada, 2010).

SR Sianturi. Asas-Asas Hukum Pidana Indonesia dan Penerapannya (Jakarta: Alumni AhaemPetehaem, 1996).

Sudarto. Hukum Pidana I (Semarang: Badan Penyedia bahan-bahan kuliah Undip, 1987).

Tempo, "Swedia Berhasil Atasi Prostitusi, Begini Caranya”, (2019), online: 〈https://dunia.tempo.co/read/666404/swedia-berhasil-atasi-prostitusibeginicaranya/full\& $\&$ view $=0 \mathrm{k}>/\rangle$.

Van Bemmelen. Hukum Pidana I Hukum Pidana Material Bagian Umum Cet. 2 (Bandung: Bina Cipta Bandung, 1987).

Widhiana Suarda. Hukum Pidana : Materi Penghapus, Peringan dan Pemberat Pidana (Malang: Bayumedia Publishing, 2012).

Widodo. Hukum Pidana di Bidang Teknologi Informasi (Yogyakarta: Aswaja Pressindo, 2013).

Yesmil Anwar \& Adang. Kriminologi (Bandung: Refika Aditama, 2010).

Yesmil Anwar dan Adang. Kriminologi (Bandung: PT. Refika Aditama, 2013). 
444 | Formulating Criminal Liabilities Regarding Online Prostitution

This page is intentionally left blank 